Article

\title{
Study of Strategic Narratives: The Case of BRICS
}

\author{
Carolijn van Noort
}

Department of Politics, University of Otago, Dunedin 9016, New Zealand; E-Mail: carolijn.vannoort@postgrad.otago.ac.nz

Submitted: 29 March 2017 | Accepted: 12 July 2017 | Published: 29 September 2017

\begin{abstract}
In the battle of narratives to give meaning to the international system in the twenty-first century, emerging powers are actively engaged. In particular, the BRICS group, comprising Brazil, Russia, India, China and South Africa, have advanced their claim to reconstitute international affairs to make it more just and fair. What if their narratives about the international system effectively contest narratives constituting the Liberal World Order? For understanding the battle more profoundly, this study examines the strategic narratives of the BRICS. A documentary methodology was employed to elicit themes and narratives in BRICS joint communiqués of 2009 to 2016 for the identification of its strategic narratives. I have identified a system narrative of global recovery, an identity narrative of inclusive participation and an issue narrative of infrastructural development. A narrative grammar was used to relate BRICS strategic narratives with their narrative environment of symbolic, institutional and material practices. Due to a partial compliance with the narrative grammatical rules, the BRICS group may not effectively influence and gain public support.
\end{abstract}

\section{Keywords}

BRICS; narrative analysis; strategic narratives; thematic analysis

\section{Issue}

This article is part of the issue "Narratives of Global Order", edited by Matthew Levinger (George Washington University, USA) and Laura Roselle (Elon University, USA).

(C) 2017 by the author; licensee Cogitatio (Lisbon, Portugal). This article is licensed under a Creative Commons Attribution 4.0 International License (CC BY).

\section{Introduction}

In the battle of narratives to give meaning to the international system in the twenty-first century, emerging powers are actively engaged (see the work of Cox, 2012; Hurrell, 2013; Ikenberry, 2011). What happens when $42 \%$ of the world population effectively contest existing narratives about the international order? As Schweller commented: "Profound dislocations throughout the global system are causing the narrative of world politics to become an increasingly fragmented and disjointed story" (Schweller, 2014, p. 9). The first decade demonstrated stunning economic growth figures in the BRICS countries, a group comprising of Brazil, Russia, India, China and South Africa. These emerging powers were artificially grouped together in a famous Goldman Sachs working paper (O'Neill, 2001; see also Wilson \& Purushothaman, 2003). The original BRIC acronym, without the "S" of South Africa, signified four large emerging market economies that had the potential to outperform the G7 countries (O'Neill, 2001). These emerging powers took major roles in the global economy, and were indispensable in the negotiation of development issues (exemplified in the Heiligendam Summit in 2007; see Cooper \& Thakur, 2013, p. 269). The global financial crisis of 2008 and its ramifications internationally perpetuated discontent with asymmetric globalization. During the first BRICS Ministerial Meeting in 2006 encouraged by the Russian Presidency, the four Foreign Ministers expressed their interests in a new consultation platform (Kirton, 2015). The dialogue propelled various ministerial meetings and the first BRIC Summit with heads of states in 2009 in Yekaterinburg, Russia (BRIC, 2009). The group advocated for reform of multilateral institutions to correspond to the economic changes of the twenty-first century (BRIC, 2009). In 2011, they enlarged its membership to South Africa (BRICS, 2011). Originally a platform on finance and good governance, the group broadened its commitments throughout the years (see for example, Larionova, Kirton, Bracht, Wang, \& Rakhmangulov, 2016). 
A much-debated question is whether this political formation makes sense, given the fast social, political and economic differences between the BRICS countries (de Coning, Mandrup, \& Odgaard, 2014; Mielniczuk, 2013; Thakur, 2014). In the global reordering of international affairs (see the work of Xing \& Shaw, 2014), the BRICS mission is to promote a "multipolar, equitable and democratic world order" (BRIC, 2010, no. 2). The formation of strong strategic narratives may shape expectations and beliefs positively, when the unstable and uncertain situation perpetuated by the economic downturn and the political crises in several of the BRICS countries are taken into account (see the fall of emerging powers, in Kiely, 2016). Recognizing BRICS continuous efforts to pursue cooperation, it is important to analyze how the formation of their public narrative make ontological sense (Somers, 1994).

The BRICS joint communiqués that are released after each annual summit capture the group's main aspirations and objectives. The communiqués stipulate a strategic script as they are "designed or nurtured with the intention of structuring the responses of others to developing events" (Freedman, 2006, p. 22). A strategic script, or in other words strategic narratives, are "representations of a sequence of events and identities, a communicative tool through which political actorsusually elites-attempt to give determined meaning to past, present, and future in order to achieve political objectives" (Miskimmon, O'Loughlin, \& Roselle, 2013, p. 5). Using a constructivist approach, it examines how rational actors construct a social, political reality (Wendt, 1994, 1999). There are three types of strategic narratives: system narratives which "are about the nature of the structure of international affairs"; identity narratives which "are about the identities of actors in international affairs that are in a process of constant negotiation and contestation"; and issue narratives which are "strategic in the sense of seeking to shape the terrain on which policy discussions take place" (Miskimmon et al., 2013, p. 7). This study is situated in the "narrative turn" in international relations (Roberts, 2006), in observation of literary studies (see the work of Barthes, 1966; Bruner, 1991; Burke, 1962; Propp, 1968; White, 1980). Using the theoretical framework of strategic narratives, the study sets out how the BRICS group gives meaning to the international system, their collective identity and the issue area of infrastructural development. The issue narrative of infrastructural development is significant for that it describes the design and implementation of ports, roads, airports, bridges, dams through "soft" technology transfer and knowledge exchange and "hard" project development, while emphasizing the sustainability element. As Schweller writes: "emerging multipolarity is attributed to the diffusion of economic, scientific, and technological power" (Schweller, 2014, p. 85).

For the critical analysis, I analyzed how BRICS strategic narratives complied to the "narrative grammar" for that full compliance would "influence the success and impact of a strategic narrative" (Dimitriu \& de Graaf, 2016, p. 7). The narrative grammar rules draw attention to "connecting (however unstable) parts to a constructed configuration or a social network of relationships (however incoherent or unrealizable) composed of symbolic, institutional, and material practices" (Somers, 1994, p. 616, italics in original). Effective compliance of these narrative grammatical rules enhances public support for BRICS mission. Strong strategic narratives have the potential to empower political actors. I examine four elements that relate to the narrative environment: mission purpose, legitimacy, the prospect of success, and the presence of counter narratives. A compelling mission purpose keeps "the focus on long-term, overarching purposes and ambitions"; legitimacy concerns both the "objective sense (judicial, procedural) and a subjective sense (political, public, ethical); the prospect of success "triggers public support for a mission" due to "an overarching storyline"; and the presence of counter narratives is a result of disagreement among political elites that is reflected in mainstream media reporting on the issues at stake (Dimitriu \& de Graaf, 2016, p. 7). The authors define a fifth indicator, which concerns the compliance of a narrative into an "overall strategic communication plan" (Dimitriu \& de Graaf, 2016, p. 7). I have chosen not to use this indicator for the analysis, because the BRICS group has not collectively formulated a strategic communication plan. Using a soft power perspective (which evidently is not so "soft", see Mattern, 2005; building on the work of Nye, 1990), BRICS joint communiqués aim to shape the behavior of international and domestic audiences and is therefore essentially strategic. These four elements provide the tools to discuss whether BRICS strategic narratives can influence and generate public support.

This paper analyzes first how the strategic narratives of the BRICS give meaning to the international system, their collective identity and the issue of infrastructural development. And second, it examines how the BRICS strategic narratives relate to a narrative environment of symbolic, institutional and material practices. Public support for the BRICS group is expected to decrease, due to partial compliance with the narrative grammatical rules.

\section{Qualitative Research Design}

This study pursued a qualitative research methodology guiding the narrative inquiry, confirming the observation that: "Researchers will mix methods together in different ways, and we expect to see in the next decade a series of patchwork, adaptive, broader methodologies" (Miskimmon, O'Loughlin, \& Roselle, 2017, p. 24). This case study about the BRICS group uses the theoretical framework of strategic narratives to examine how their political communication is persuasive. I have pursued a qualitative research process, i.e. a documentary methodology, to understand how a credible storyworld is evoked in BRICS joint communiqués. Documents can be used to reconstitute the meaning of international affairs, "so as to de- 
velop and underpin particular visions of the world and the things and events within that world" (Prior, 2011, p. 67). The data set for this paper comprise of the BRICS joint communiqués from 2009 to 2016. Pursuing a theory driven analysis, the results created "more a detailed analysis of some aspect of the data" (Braun \& Clark, 2006, p. 84). It discusses the ontological features of BRICS strategic narratives; it does not analyze the causal impact of BRICS strategic narratives and the actual increase or decrease of public support. Thus, I have taken interpretivist ontology to learn how meaning is generated within the documents (Grix, 2002, p. 178). Table 1 sets out the qualitative research design for this study.

Reading addressed both the explicit, communicative meaning and the implicit, conjunctive meaning in the documents (Bohnsack, 2013, p. 225; Feldmand \& Almquist, 2012). Documents convey political interests as they are "created for a particular purpose, crafted according to social convention to serve a function of sorts" (Coffey, 2013, p. 369). The textual reading of BRICS joint communiqués was structured in six phases (see Table 2).

After the first two phases in which I organized the documents and designed a coding framework, I situated the narrative components of the BRICS story in phase 3 using Kenneth Burke's framework of dramatism (Burke, 1962). Accordingly, "language is best seen as an enact- ment, as a symbolic selection of circumference, which gives entities an identifiable character (or substance)" (Crable, 2000, p. 329). The who, when and where, what, how and why questions contextualized the actions and motives for BRICS cooperation. Phase 4 and 5 went deeper into BRICS political communication by employing a narrative and thematic analysis for the analysis of mutual constituting aspects of content and form (narrative). Accordingly, the "paradigmatic type uses an analytic process that identifies aspects of the data as instances of categories; the narrative type uses an analytic process that produces storied accounts" (Polkinghorne, 1995, p. 21). Thematic and narrative structural analyses complement each other, because they both "lend themselves to constructionist paradigms that view experiences, meanings and social structures as mutually constitutive" (Shukla, Wilson, \& Boddy, 2014, p. 3). The identified themes are "not necessarily dependent on quantifiable measuresbut rather on whether it captures something important in relation to the overall research question" (Braun \& Clarke, 2006, p. 82). The search for causal emplotment in phase 5 identified how the sequence of events were assembled in a coherent narrative. It analyzed how for example narratives about the reform of international institutions and the intensification of intra-BRICS mutually beneficial cooperation may positively affect the aspira-

Table 1. Qualitative research design for study of strategic narratives.

\begin{tabular}{llllllll}
\hline $\begin{array}{l}\text { Research } \\
\text { Design }\end{array}$ & Methodology & $\begin{array}{l}\text { Pivotal } \\
\text { cognitive } \\
\text { modes }\end{array}$ & $\begin{array}{l}\text { Research } \\
\text { types }\end{array}$ & $\begin{array}{l}\text { Gathering } \\
\text { structure }\end{array}$ & $\begin{array}{l}\text { Data } \\
\text { collection } \\
\text { techniques }\end{array}$ & $\begin{array}{l}\text { Data } \\
\text { management } \\
\text { techniques }\end{array}$ & $\begin{array}{l}\text { Data analysis } \\
\text { techniques } \\
\text { techniques }\end{array}$ \\
\hline Case Study & Documentary & Reading & Textual & Structured & Documents & Coding & $\begin{array}{l}\text { Thematic } \\
\text { analysis } \\
\end{array}$ \\
& & & & & & & Narrative \\
analysis & & & & & & &
\end{tabular}

Table 2. Six phases of the documentary methodology.

\begin{tabular}{|c|c|c|c|c|c|}
\hline Phase 1 & Phase 2 & $\begin{array}{l}\text { Phase } 3 \text { Codes } \\
\text { Descriptive coding } \\
\text { of narrative } \\
\text { components }\end{array}$ & $\begin{array}{l}\text { Phase } 4 \\
\text { Thematic } \\
\text { analysis } \\
\text { Step 1: Thematic } \\
\text { coding } \\
\text { Step 2: Searching } \\
\text { for themes }\end{array}$ & $\begin{array}{l}\text { Phase } 5 \\
\text { Narrative } \\
\text { analysis } \\
\text { Step 1: Narrative } \\
\text { coding } \\
\text { Step 2: Searching } \\
\text { for causal } \\
\text { emplotment }\end{array}$ & $\begin{array}{l}\text { Phase } 6 \text { Strategic } \\
\text { codes } \\
\text { Constitute themes and } \\
\text { narrative structures in } \\
\text { three types of strategic } \\
\text { narratives }\end{array}$ \\
\hline $\begin{array}{l}\text { Organizing } \\
\text { the } \\
\text { documents } \\
\text { in excel files. } \\
\text { Reading and } \\
\text { writing } \\
\text { down initial } \\
\text { ideas }\end{array}$ & $\begin{array}{l}\text { Tagging and } \\
\text { designing a } \\
\text { coding } \\
\text { framework }\end{array}$ & $\begin{array}{l}\text { Act (what) } \\
\text { Scene (where and } \\
\text { when) } \\
\text { Agent (who) } \\
\text { Agency (how, by } \\
\text { what means) } \\
\text { Purpose (why) }\end{array}$ & $\begin{array}{l}\text { 1. Thematic } \\
\text { coding } \\
\text { 2. Themes } \\
\text { Sub themes }\end{array}$ & $\begin{array}{l}\text { 1. Narrative } \\
\text { coding } \\
\text { 2. Narratives } \\
\text { and } \\
\text { emplotment }\end{array}$ & $\begin{array}{l}\text { 1. Constitute themes } \\
\text { and narrative } \\
\text { structures in } \\
\text { system narrative, } \\
\text { identity narrative } \\
\text { and issue narrative } \\
\text { 2. Create a coherent } \\
\text { report }\end{array}$ \\
\hline
\end{tabular}


tion for a more fair and democratic multipolar world order. The last phase integrated the results through the conceptual framework of strategic narratives, which is disclosed below.

\section{BRICS Strategic Narratives}

In the BRICS joint communiqués, a system narrative of global recovery; an identity narrative of inclusive participation; and an issue narrative of infrastructural development were identified. The themes in each of these narratives emphasize responsive multilateralism, a culture of equity and strategic synergies respectively. Under the premises "that the $21^{\text {st }}$ century should be marked by peace, security, development, and cooperation" (BRICS, 2013, no 22), the BRICS group aspires "a more democratic and just multi-polar world order" (BRICS, 2009, no 12). In this part, I will discuss the strategic narratives that I identified in BRICS joint communiqués.

\subsection{Strategic System Narrative of Global Recovery}

BRICS strategic system narrative of global recovery addresses good governance, in particular in the area of finance, economics and international security and a central role for the G20 Summits "in dealing with the financial crisis" (BRIC, 2009, № 1). The imagined recuperation presupposes a revival of economic growth, as well as the restructuring of multilateral institutions to counter "the risk of seeing them fade into obsolescence" (BRIC, 2010, no 11). A reformed multilateral system should support a "strong client orientation that recognizes each country's development needs" (BRICS, 2014a, no 19). The principle of "common but differentiated responsibilities" is an important element in this narrative (BRICS, 2012, no 22). The recovery is not proposing a counter challenge against existing market capitalism practices. It accommodates both short-term goals, i.e. the annual meetings and workshops; as well long-term pursuits, aligned with the sustainable development goals and economic growth exemplified in their "roadmap for trade, economic and investment cooperation until 2020" (BRICS, 2016, no 36).

The central theme in this system narrative suggests how multilateralism symbolizes a cornerstone function for sovereign states. Institutions such as the United Nations are essential to address transnational issues involving trade and security. Multilateralism is seen compatible with sovereignty, as they "insist that international law provides tools for achieving international justice, based on principles of good faith and sovereign equality" (BRICS, 2015a, no 6). In their search to make multilateral institutions more accountable and legitimate, the communiqués encourage honorable behavior. In particular, they promote responsible macroeconomic policy and compliance with official development aid (see BRICS, $2013, n=7,2016$, $n$ ㅇ 22). The BRICS group originates from a tradition of multilateral dialogues, exemplified by the repeated citing of the United Nations' $70^{\text {th }}$ anniversary (see BRICS, 2014a, 2015a, 2016). Furthermore, the aspired global recovery is causally emplotted as to foster sustainable development and global peace. The BRICS group is actively engaged with a post-2015 development agenda and the Sustainable Development Goals adopted in 2015 (BRICS, 2015a, no 65). Therefore, a strategic system narrative of global recovery imagines responsive and legitimate multilateral institutions that foster the political interests of sovereign states.

\subsection{Strategic Identity Narrative of Inclusive Participation}

The joint communiqués strategically communicate an identity narrative of inclusive participation. The advocacy for more voice and representation communicated in their system narrative is supported by a narrative account of their collective identity as responsible, mature, pro-active emerging powers. These emerging countries advocate for inclusive participation as a conditional to re-order international affairs in a sustainable way. The leitmotifs of the 2014 and 2016 BRICS summits reinforce this vision of negotiation, i.e. "inclusive growth, sustainable solutions" and "building responsiveness, inclusive and collective solutions" (BRICS, 2014a, 2016). There is a strong commitment to the $\mathrm{G} 20$ on the premises of inclusive participation: "Compared to previous arrangements, the $\mathrm{G}-20$ is broader, more inclusive, diverse, representative and effective" (BRIC, 2010, no 3). The BRICS group causally emplot an identity narrative of inclusive participation as mutually constitutive to their system narrative of global economic recovery.

The central theme identified in this narrative is equity, which encourages fair play instead of positive affirmation. For example, they advocate for the treatment of "all human rights, including the right to development, in a fair and equal manner, on the same footing and with the same emphasis" (BRICS, 2014a, no 30). Competitiveness is imagined as an outcome of an equitable international system. Inclusive participation is advocated through representative experiences of political leadership. For example, the performance of the respective members to host high profile events is praised: "We commend China for the successful hosting of the $11^{\text {th }}$ G20 Leaders' Summit in Hangzhou" (BRICS, 2016, no 41) and "We congratulate Brazil on hosting the UN Conference on Sustainable Development" (BRICS, 2013, no 35). The emphasis in this narrative is on how inclusive decision-making in international affairs exemplifies fairness.

\subsection{Strategic Issue Narrative of Infrastructural Development}

The issue narrative of infrastructural development is significant in the BRICS joint communiqués. It concerns the mobilization of infrastructure investments and the promotion of physical infrastructure respectively. The narrative of inclusive participation propelled a range of intra- 
BRICS cooperation schemes, with the New Development Bank as its flagship. The documents encourage proactive behavior, "for the development of action-oriented economic cooperation and systematic strengthening of economic partnership for the recovery of the global economy" (BRICS, 2015a, no 12). Cooperation is envisioned in many issue areas, in which I interpreted infrastructure financing and development to be the main foci. This issue narrative of infrastructural development empowers BRICS identity narrative of inclusive participation for that it provides structural tools that are responsive and equitable. It also recounts a bottom up approach in which infrastructural development may translate into an economic global recovery. The main theme in this narrative is feasible and strategic synergies for prosperity. Therefore, infrastructural development communicates a social reality defined by synergy in un(der) explored areas of cooperation. The strategic framework that is envisioned aims to "strengthen cooperation in science, technology and innovation with the purposes of promoting inclusive and sustainable social and economic development [and] providing a new quality of growth based on economic complementarity" (BRICS, 2015a, no 62). The complementary cooperation that is aspired envisions an honest South-South dialogue. It celebrates the expertise in the country, the possible export of "best practice", and the promotion of fruitful enterprises. The issue narrative of infrastructural development communicates connectivity between the promotion and financing of institutional, physical and people-to-people interactions.

\section{Compliance Narrative Grammar}

To understand whether the BRICS group is expected to gain support for their mission to foster a fair and democratic multipolar world order, I have used the "narrative grammar" for the evaluation of BRICS strategic narratives (Dimitriu \& de Graaf, 2016, p. 7). This part examines how BRICS strategic narratives articulate a credible storyworld, juxtaposing the strategic narratives in relation to a narrative environment of symbolic, institutional and material practices.

\subsection{Mission Purpose}

At its essence, it is not well-defined how BRICS the "economic story" of five emerging market economies and BRICS the institutionalized "political story" are mutually constitutive. The challenge is to interconnect the two stories: "working from economic reality to a tighter sense of normative and ideational identity amongst the grouping's membership" (Cooper \& Thakur, 2013, p. 274). The communication of global recovery is fairly unsubstantiated, given that these "emerging powers have produced neither a unified ideology, nor a new institutional framework for global governance that is politically and ideologically universal" (Xing, 2016, p. 50). Multipolarity can be classified as the least stable international order (Mur- ray, 2016, p. 95). It is unclear in the texts how the global recovery is peaceful and fair in light of the loose contract between sovereign states and their commitment to multilateralism.

In comparison to BRICS strategic system narrative, BRICS identity and issue narratives promote more clearly how a democratic and equitable multipolar world should look like. Advocacy for inclusive participation is projected as a natural development, considering that their participation is essential in addressing global challenges (see for example the Heiligendam process). It particularly aims to shape a preferred narrative of decision-making processes. With respect to BRICS issue narrative of infrastructural development, this causally connects energy, telecommunication and transport sectors for the benefit of sustainable development (BRICS, 2016, no 62). The establishment of the New Development Bank responds to the real and persistent gap in infrastructure financing (BRICS, 2013, no 9). There is the demand for infrastructure and commodities, as well as existence of in-house knowledge, resources and technology (see analyses on complementary cooperation, for example Mudunuru, 2013, p. 65). The New Development Bank exemplifies the do-it-yourself attitude of the BRICS.

\subsection{Legitimacy}

The reordering of the world is pursued through legitimate procedures, i.e. reform to address the underrepresentation of emerging and developing countries. However, in the subjective sense it fails to comprehensively account for the political and cultural divergences between the five member states. For example, the credibility of these countries to pursue a democratic world order is weak, given the (semi) authoritarian regimes of two of the five BRICS members (Abdenur \& Folly, 2015, p. 88). BRICS system narrative of global recovery does not fully legitimize their mission of a fair and democratic multipolar world order.

According to the same argument, inclusive participation has been performed in the procedural sense but is not entirely attuned to diverging cultural norms and values. Since 2013, regional leaders have been invited to attend the BRICS Summits (see BRICS, 2013). However, the BRICS group advocate for the emerging and developing countries, without necessarily attaining this regional leadership position (see the work on Brazil and South Africa, by Vieira \& Alden, 2011). Also, the encouragement of intra-BRICS meetings of non-state actors (i.e. civil society, academic community) articulates a democratic and fair decision-making processes. Again, in the subjective sense it does not provide compelling arguments for why these processes are credible open spaces for narrative contestation of state narratives.

The same is acknowledged in BRICS issue narrative of infrastructural development narrative. It is procedurally legitimate, given the integration of these countries in the global economy. Complementary cooperation is 
credible, given that the group includes "the factory of the world (China), the garden of the world (Brazil), the gas station of the world (Russia)..., the back office of the world (India)" and South Africa as the "African Gateway" (Kahn, 2011a, p 493, 2011b, p. 496). But is does not attend to economic power imbalances, and therefore new expected emerging economic hierarchies.

\subsection{Prospect of Success}

BRICS system narrative of global recovery is not clearly stipulating an overarching storyline that promises success. Originally a consultation group on finance and good governance, the BRICS group expanded its issue areas. Evidently, this complicates the measuring of success given that there are "no tangible policy measures and specific projects are announced following the talks" (Liu, 2016, p. 450). It affects the apprehension of the cooperation, because "without clearly formulated policy goals at the start, it is quite cumbersome to design them once the mission is underway" $(2016$, p. 11). Furthermore, the stunning growth and performance of the initial decade are difficult to repeat. In particular, "now that the BRICs story is better known, expectations are higher and the valuation gap is much smaller" (Wilson, Kelston, \& Ahmed, 2010, p. 1). Also, adverse events (i.e. economic downturn and political challenges, see Talley, 2016; Tisdal, 2016) are not comprehensively emplotted in BRICS joint communiqués. Therefore, the causal emplotment of events are not effectively narrated in a success narrative. Correspondingly, "the tectonic plates of global politics are certainly shifting, but their movements are yet not predictable" (Pant, 2013, p. 103). A clear roadmap that addresses BRICS means, ways and ends would improve the political communication.

BRICS identity narrative of inclusive participation aims to shape both the behavior of international and domestic audiences. It advocates for reform on the global level, as well as it promotes multi-stakeholdership in domestic debates. A "horizon of success and progress" (Dimitriu \& de Graaf, 2016, p. 7) is indicative when nonstate actors, i.e. civil society and academics, have measurable participatory influence on narrative contestation on the national and subsequently the multilateral level. Commitments for non-state actors' participation tend to have a secondary position in the BRICS joint communiques (see numerical order of commitments incorporating the participation of non-state actors), emphasizing the prioritized role of sovereign states to contest and constitute narratives of international order.

To judge the promise of success expressed by BRICS issue narrative of infrastructural development is arguably premature. The establishment of the New Development Bank is very recent (see BRICS, 2014b, 2015b), and the ability to mobilize resources is a matter of time. However, emphasis on connectivity in the communiqués is indicative of an aspired political reality that accommodates their infrastructure bottlenecks through the provi- sion of accommodating solutions (i.e. in contrast to conditioned International Monetary Fund loans). This narrative resonates with BRICS identity narrative of inclusive participation through its democratic governance and selfdefined policies.

\subsection{Presence of Counter Narratives}

In terms of the compliance of BRICS strategic narratives with the narrative grammatical rule of presence or absence of counter narratives, this is largely based on implicit reading. Paratextual, both academic papers and news articles signal more explicitly the presence of counter narratives. Accordingly, the "greater the dissent, the better the possibility that the media will start inscribing these political dissenting voices, that is, counternarratives, into their dichotomous media frames" (Dimitriu \& de Graaf, 2016, p. 12). BRICS reordering of the world does not accommodate the asymmetric power balances between the BRICS countries, i.e. China's disproportionate political and economic weight. The economic downturn undermined the narrative coherence of BRICS the "economic story". The reporting on the closure of Goldman Sachs' BRICs investment fund perpetuated this reading (losebashvili, 2015). These concerns about BRICS means to pursue global recovery and China's disproportionate economic weight perpetuate counter narratives.

The issue narrative of inclusive participation is a pragmatic approach to cope with global governance and development challenges. In practice, instances of political discontent were effectively concealed in the communiqués, albeit emphasized in media reports. Russia's annexation of Crimea and intervention in Ukraine in 2014 forced the powers to conceal their unease about the violation of the sovereignty principle. Unmistakably referring to the international isolation of Russia, the joint communiqués denounces "unilateral military interventions and economic sanctions in violation of international law and universally recognized norms of international relations" (BRICS, 2014a, no 27). Furthermore, news reports of the Goa Summit highlighted the tension between India and China on the issue of state-sponsored Pakistani terrorist groups (Parashari, 2016). At the same meeting, Russian President Vladimir Putin presumably declined a private meeting with Brazilian President Michel Temer, as he disapproved the impeachment of "comrade" Dilma Rousseff (Escobar, 2016). Inclusive participation should not come at the expense of sovereign power; therefore "none of these newly-empowered, rising developing nations will agree to limit their own sovereignty or to allow supranational bodies" (Fituni, 2014, p. 107). The informal contract between sovereign states and their commitment to multilateralism therefore evokes a cherry-pick approach of policy areas that are least prone to be politically sensitive. It signifies that the aspired decisionmaking processes surpasses the necessity to agree on all issue areas. 
Lastly, BRICS issue narrative of infrastructural development encounters various counter narratives articulated by non-state actors in the BRICS countries. While BRICS identity narrative of inclusive participation promoted the participatory role of civil society, this promise did not promote a new (infrastructural) development paradigm with a large support. Originally, civil society supported the BRICS coordination, as it thought to be a counter hegemonic challenge. What arguably divides the coherency of this issue narrative, is "that the coalition, and the NDB [New Development Bank] more specifically, are being shaped in ways that favor the interests and values of the two autocratic members" (Abdenur \& Folly, 2015, p. 88; Kiely, 2016, p. 33). Good governance and development discriminates the issue narrative therefore in two camps: the "IBSA" countries (Brazil, India, South Africa) in the one camp, and Russia and China in the other. Other types of counter narratives originate in the critique on BRICS endorsement of the neoliberal development model (Taylor, 2014), exemplified by the BRICS-from-Below movement (see the work of Bond \& Garcia, 2015). It assumes an existential incompatibility between infrastructural development as imagined by the BRICS group and a desirable fair and just multipolar world order.

\section{In Conclusion}

This paper examined how the BRICS group gives meaning to the international system, their collective identity and the issue of infrastructural development and how these BRICS strategic narratives relate to a narrative environment of symbolic, institutional and material practices. Using a documentary analysis, I identified a system narrative of global recovery, an identity narrative of inclusive participation, and an issue narrative of infrastructural development respectively. Due to partial compliance of BRICS strategic narratives with the narrative grammatical rules, the BRICS group may not effectively generate public support for their proposed reordering of the world. The narratives convey procedural legitimacy, but fail to address a narrative environment of symbolic, institutional and material practices. Without causal implications of tangible indicators and achieved successes, BRICS joint communiques fail to communicate a temporal sequence of events and therefore a (promised) indication of success. The presence of counter narratives is arguably negligible. However, the BRICS group as a whole may lose relevance due to an implicit reading of China's asymmetric weight and the choice to not emplot adverse events such as the economic downturn and political challenges into a coherent narrative.

The analysis discussed the ontological dimensions of BRICS strategic narratives. It did not seek to answer whether the narratives effectively changed domestic and international behavior. Furthermore, qualitative research on how member states contest BRICS strategic narratives would demonstrate how the battle of narra- tives within the BRICS group is effecting the narratives' coherency and strength. Evidently, this paper is a shortened version (full analysis on formation and narrative contestation on this formation to be included in the author's doctoral). For future reference, the mutual constitutive interaction between the visual imagery (Crilley, 2015) of BRICS annual summits (i.e. logo and websites) and the joint communiqués would improve the ontological analysis of BRICS strategic narratives.

\section{Acknowledgments}

The author wishes to thank her supervisors, Dr. Chris Rudd and Dr. Hugh Slotten, for their helpful guidance and comments, as well as the University of Otago for their generous Otago scholarship.

\section{Conflict of Interests}

The author declares no conflict of interests.

\section{References}

Abdenur, A. E., \& Folly, M. (2015). The new development bank and the institutionalization of the BRICS. Revolutions: Global Trends and Regional Issues, 3(1), 1-215.

Barthes, R. (1966). An introduction to the structural analysis of narrative (L. Duisit Transl.). New Literary History, 6(2), 237-272.

Bond, P., \& Garcia, A. (Eds.). (2015). BRICS: An anticapitalist critique. London: Pluto Press.

Bohnsack, R. (2013). Documentary method. In U. Flick (Ed.), The SAGE handbook of qualitative data analysis (pp. 217-233). London: Sage.

Braun, V., \& Clarke, V. (2006). Using thematic analysis in psychology. Qualitative Research in Psychology, 3(2), 77-101.

BRIC. (2009, June 16). First summit: Joint statement of the BRIC countries' leaders. Retrieved from http:// www.brics.utoronto.ca/docs/index.html\#goa

BRIC. (2010, April 15). Second BRIC summit of heads of state and government: Joint statement. Retrieved from http://www.brics.utoronto.ca/docs/ index.html\#goa

BRICS. (2011, April 14). Sanya declaration and action plan. Retrieved from http://www.brics.utoronto.ca/ docs/index.html\#goa

BRICS. (2012, March 29). Delhi declaration and action plan. Retrieved from http://www.brics.utoronto.ca/ docs/index.html\#goa

BRICS. (2013, March 27). eThekwini declaration and action plan. Retrieved from http://brics5.co.za/aboutbrics/summit-declaration/fifth-summit

BRICS. (2014, July 15). Fortaleza declaration and action plan. Retrieved from http://brics.itamaraty.gov.br/ category-english/21-documents/223-sixth-summitdeclaration-and-action-plan

BRICS. (2014, July 15). Agreement on the New De- 
velopment Bank. Retrieved from http://www.brics. utoronto.ca/docs/140715-bank.html

BRICS. (2015, July 9). Ufa declaration and action plan. Retrieved from http://en.brics2015.ru/documents

BRICS. (2015, July 9). Memorandum of understanding on cooperation with the New Development Bank. Retrieved from http://www.brics.utoronto.ca/ docs/150709-NDB-memorandum-en.html

BRICS. (2016 October 16). Goa declaration and action plan. Retrieved from http://brics2016.gov.in/upload/ Goa\%20Declaration\%20and\%20Action\%20Plan.pdf

Bruner, J. (1991). The narrative construction of reality. Critical Inquiry, 18(1), 1-21.

Burke, K. (1962). A grammar of motives and a rhetoric of motives. Cleveland, $\mathrm{OH}$ : The World Publishing Company. (Original work published in 1945 and 1950)

Coffey, A. (2013). Analysing documents. In U. Flick (Ed.), The SAGE handbook of qualitative data analysis (pp. 367-379). London: Sage.

Cooper, A., \& Thakur, R. (2013). The BRICs in the new global economic geography. In T. Weiss \& R. Wilkinson (Eds.), International organization and global governance (pp. 265-278). Florence: Taylor and Francis.

Cox, M. (2012). Power shifts, economic change and the decline of the West? International Relations, 26(4), 369-388.

Crable, B. (2000). Defending dramatism as ontological and literal. Communication Quarterly, 48(4), 323-342.

Crilley, R. (2015). Seeing strategic narratives? Critical Studies on Security, 9(3), 331-333.

de Coning, C., Mandrup, T., \& Odgaard, L. (2014). The BRICS and coexistence: An alternative vision. Hoboken, NJ: Taylor and Francis.

Dimitriu, G., \& de Graaf, B. (2016). Fighting the war at home: Strategic narratives, elite responsiveness, and the Dutch mission in Afghanistan, 2006-2010. Foreign Policy Analysis, 12, 2-23.

Escobar, P. (2016, October 18). BRICS continues its advance, one step at a time. Russia Today. Retrieved from https://www.rt.com/op-edge/363181brics-advance-step-time

Feldman, M., \& Almquist, J. (2012). Analyzing the implicit in stories. In J. Holstein \& J. Gubrium (Eds.), Varieties of narrative analysis (pp. 207-228). Thousand Oaks, CA: Sage Publications.

Fituni, L. (2014). From boulders to ashlars-BRICS of a new world order: Hierarchies of power and degrees of freedom in the emerging world system of the twenty-first century. In L. Xing \& T. Shaw (Eds.), BRICS and beyond the international political economy of the emergence of a new world order (pp. 93-110). Farnham: Ashgate Publishing Ltd.

Freedman, L. (2006). The transformation of strategic affairs. Oxon: Routledge.

Grix, J. (2002). Introducing students to the generic terminology of social research. Politics, 22(3), 175-186.

Hurrell, A. (2013). Narratives of emergence: Rising pow- ers and the end of the third world? Brazilian Journal of Political Economy, 33(2), 203-221.

Ikenberry, J. (2011). The future of the liberal world order: Internationalism after America. Foreign Affairs, 90(3), 56-68.

Iosebashvili, I. (2015, November 9). Goldman closes BRIC fund. Wall Street Journal. Retrieved from https:// www.wsj.com/articles/goldman-closes-bric-fund-14 47116375

Kahn, M. (2011a). The BRICs and South Africa as the gateway to Africa. The Journal of the Southern African Institute of Mining and Metallurgy, 111(7), 493-496.

Kahn, M. (2011b). The fall of the wall, the rise of the BRICs and the new scramble for Africa. Foresight, 13(3), 38-49.

Kiely, R. (2016). The rise and fall of emerging powers globalisation, US power and the global north-south divide. Cham: Springer International Publishing.

Kirton, J. (2015). Explaining the BRICS summit solid, strengthening success. International Organisations Research Journal, 10(2), 1-29.

Larionova, M., Kirton, J., Bracht, C., Wang, A. X., \& Rakhmangulov, M. (2016). 2015 BRICS ufa compliance report (BRICS Research Group Report). Retrieved from http://brics.utoronto.ca/ compliance/2015-ufa-compliance.pdf

Liu, M. (2016). BRICS development: A long way to a powerful economic club and new international organization. The Pacific Review, 29(3), 1-11.

Mattern, J. B. (2005). Why 'soft power' isn't so soft: Representational force and the sociolinguistic construction of attraction in world politics. Millennium: Journal of International Studies, 33(3), 583-612.

Mielniczuk, F. (2013). BRICS in the contemporary world: Changing identities, converging interests. Third World Quarterly, 34(6), 1075-1090.

Miskimmon, A., O'Loughlin, B., \& Roselle, L. (2013). Strategic narratives: Communication power and the new world order. New York, NY: Routledge.

Miskimmon, A., O'Loughlin, B., \& Roselle, L. (Eds.). (2017). Forging the world: Strategic narratives and international relations. Ann Arbor, MI: University of Michigan Press.

Mudunuru, L. (2013). BRICS in a multi-polar world: The emerging geopolitical landscape. In J. M. Munoz (Ed.), Handbook on the geopolitics of business (pp. 64-75). Cheltenham: Edward Elgar Publishing.

Murray, R. (Ed.). (2016). Seeking order in anarchy: Multilateralism as state strategy. Edmonton: The University of Alberta Press.

Nye, J. S. (1990). Soft power. Foreign Policy, 80, 153-171.

O’Neill, J. (2001). Building better global economic BRICs. Goldman Sachs, 66, 1-16.

Pant, H. (2013). The BRICS fallacy. The Washington Quarterly, 36(3), 91-105.

Parashari, S. (2016, October 17). BRICS summit: China bulldozed India's security concerns as Russia looked the other way. The Times of India. Retrieved from 
http://timesofindia.indiatimes.com/india/China-bull dozed-Indias-security-concerns-as-Russia-looked-the -other-way/articleshow/54903013.cms

Polkinghorne, D. E. (1995). Narrative configuration in qualitative analysis. International Journal of Qualitative Studies in Education, 8(1), 5-23.

Prior, L. (2011). Using documents in social research. London: Sage.

Propp, V. (1968). Morphology of the folktale (L. Scott Transl.). Austin, TX, and London: University of Texas Press.

Roberts, G. (2006). History, theory and the narrative turn in IR. Review of International Studies, 32(4), 703-714.

Schweller, R. (2014). Maxwell's demon and the golden apple: Global discord in the new millennium. Baltimore, MD: Johns Hopkins University Press.

Shukla, N., Wilson, E., \& Boddy, J. (2014). Combining thematic and narrative analysis of qualitative interviews to understand children's spatialities in Andhra Pradesh, India (Novella Working Paper: Narrative Research in Action). Retrieved from http:// eprints.ncrm.ac.uk/3269

Somers, M. R. (1994). The narrative constitution of identity: A relational and network approach. Theory and Society, 23(5), 605-649.

Talley, I. (2016, January 19). BRICS new world order is now on hold. The Wall Street Journal. Retrieved from http://www.wsj.com/articles/brics-new-worldorder-is-now-on-hold-1453240108

Taylor, I. (2014). Africa rising? BRICS diversifying dependency. Woodbridge: Boydell and Brewer.
Thakur, R. (2014). How representative are BRICS? Third World Quarterly, 35(10), 1791-1808.

Tisdal, S. (2016, May 27). Has the BRICS bubble burst? The Guardian. Retrieved from https:// www.theguardian.com/business/2016/mar/27/bricsbubble-burst-brazil-russia-india-china-south-africa

Vieira, M. A., \& Alden, C. (2011). India, Brazil, and South Africa (IBSA): South-South cooperation and the paradox of regional leadership. Global Governance, 17(4), 507-528.

Wendt, A. (1994). Collective identity formation and the international state. American Political Science Review, 88(2), 384-396.

Wendt, A. (1999). Social theory of international politics. Cambridge: Cambridge University Press.

White, H. (1980). The value of narrativity in the representation of reality. Critical Inquiry, 7(1), 5-27.

Wilson, D., \& Purushothaman, R. (2003). Dreaming with BRICs: The path to 2050. Goldman Sachs, 99, 1-22.

Wilson, D., Kelston, A., \& Ahmed, S. (2010). Is this the 'BRICs decade'? BRICs Monthly, 10(3), 1-4.

Xing, L., \& Shaw, T. (2014). BRICS and beyond the international political economy of the emergence of a new world order. Farnham: Ashgate Publishing Ltd.

Xing, L. (2016). From 'hegemony and world order' to 'interdependent hegemony and world re-order'. In S. F. Christensen \& L. Xing (Eds.), Emerging powers, emerging markets, emerging societies (pp. 30-54). Houndmills, Basingstoke, and Hampshire: Palgrave Macmillan.

\section{About the Author}

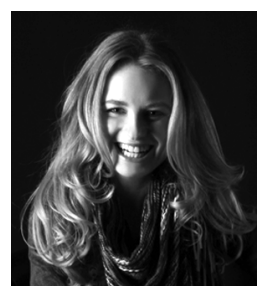

Carolijn van Noort is a PhD Candidate at the Department of Politics at the University of Otago. Of Dutch citizenship, Carolijn received a Master in Global Business Management at the Universitat Autónoma de Barcelona, a Bachelor and Master in Media \& Culture at the Universiteit van Amsterdam, and she pursued by means of student exchanges, courses in international relations and communication science at San Francisco State University and Simon Fraser University. Her research interests include strategic narratives and public diplomacy. 